\title{
PERAN SERTA PKK DALAM MENSEJAHTERAKAN KAUM LANJUT USIA
}

Oleh

Endang Yuliana Susilawati

Fakultas Hukum UNISRI

0006076701

Eyuliana046@gmail.com

\begin{abstract}
Pengabdian kepada masyarakat berupa penyuluhan hukum ini dilakukan karena tanggung jawab mensosialisasikan peraturan perundang-undangan yang berlaku, khususnya undangundang nomor 13 tahun 1998 tentang Kesejahteraan Lanjut Usia yang meski telah berusia dua puluh tahun namun belum banyak diketahui oleh masyarakat. Kegiatan ini bertujuan memberikan pengetahuan dan menjadikan paham tentang adanya kewajiban kita sebagai warga masyarakat untuk turut berperan serta dalam meningkatkan kesejahteraan kaum lanjut usia sebagaimana diamanatkan dalam undang-undang tersebut. Mitra kegiatan adalah PKK desa Malangjiwan, kecamatan Colomadu, kabupaten karanganyar. Metode yang digunakan adalah ceramah dan diskusi. Hasilnya bisa dipahamkan bahwa upaya meningkatkan kesejahteraan kaum lanjut usia merupakan tanggungjawab pemerintah, namun dukungan dan peran serta masyarakat sangat dibutuhkan untuk mewujud nyatakannya.
\end{abstract}

Kata kunci: upaya, peningkatan, kesejahteraan, lanjut usia

Community service in the form of legal counseling is carried out because the responsibility to socialize the prevailing laws and regulations, especially law number 13 of 1998 concerning Elderly Welfare which, although it is twenty years old, is not yet widely known by the public. This activity aims to provide knowledge and make it understand the obligation of us as citizens to participate in improving the welfare of the elderly as mandated in the law. The activity partners are PKK Malangjiwan village, Colomadu sub-district, karanganyar district. The method used is lecture and discussion. The result can be understood that efforts to improve the welfare of the elderly are the responsibility of the government, but the support and participation of the community is very much needed to manifest it.

Keywords: effort, improvement, welfare, elderly

PENDAHULUAN 
Mensejahterakan kaum lanjut usia dalam kehidupan sehari hari masyarakat kita yang agamis sebenarnya merupakan hal yang biasa dilakukan sebagai wujud pengamalan menjalankan perintah agama. Menghormati orang yang lebih tua telah ditanamkan kepada kita sejak masih kecil. Namun demikian sebagai warga negara Indonesia, selain hukum agama kita juga harus patuh pada hukum negara. Undang-undang yang mengamanatkan kepada pemerintah dengan dibantu warga masyarakat untuk bertanggungjawab mensejahterakan kaum lanjut usia telah diberlakukan sejak tahun 1998, yaitu UndangUndang Nomor 13 Tahun 1998 Tentang Kesejahteraan Lanjut Usia.

Dua puluh tahun sudah undang-undang tersebut telah diberlakukan di Indonesia, namun pada kenyataannya tidak banyak anggota masyarakat yang mengetahuinya, bahkan dikalangan akademispun juga demikian halnya. Sedangkan dalam praktek pelaksanaannya pemerintahan telah menjalankan sedikit dari pelayanan yang seharusnya dilakukan sebagai upaya mensejahterakan kaum lansia, misalnya adanya bantuan sosial, pelayanan kesehatan. Lebih banyak pelayanan yang belum bisa diberikan kepada kaum lansia agar merasakan sejahtera di sisa usianya.

Menghadapi situasi yang demikian maka sebagai akademisi yang mempunyai tugas tridharma yaitu melaksanakan pengajaran, melaksanakan penelitian dan melaksanakan pengabdian kepada masyarakat, maka tim merasa terpanggil dan perlu untuk mensosialisasikan undang-undang tentang lanjut usia tersebut kepada masyarakat. Dipilihlah ibu-ibu pengurus PKK sebagai sasaran yang dianggap tepat untuk dijadikan mitra dalam menyebarluaskan kepada seluruh masyarakat, khusunya kepada kaum ibu anggota PKK terlebih dahulu.

PKK merupakan organisasi yang anggotanya adalah kaum perempuan yang dibina untuk menjadi insan yang mampu memberdayakan dan mensejahterakan keluarganya. Dengan harapan setelah memperoleh pengetahuan, para pengurus PKK tersebut juga mendapatkan pemahaman serta kemudian dipraktekkan menjadi pengamalan dalam mensejahterakan kaum lanjut usia yang diamanatkan oleh undang -undang no 13 tahun 1998 tersebut. Tujuan ini sangat sejalan dengan tujuan dari keberadaan organisasi PKK.

Desa Malangjiwan yang masuk wilayah kecamatan Colomadu kabupaten Karanganyar dipilih sebagai lokasi pelaksanaan pengabdian pada masyarakat dalam bentuk penyuluhan hukum. Lokasinya kurang lebih berjarak delapan kilo meter dari kampus dengan 
kondisi jalan yang bagus. Program kegiatan PKK di desa tersebut teragendakan dengan baik dan rutin, baik untuk tingkat desa, kebayanan, maupu per dukuh. Sehingga ketika tim penyuluh ingin mengisi pada acara rutin mereka tinggal memilih waktu yang cocok antara jadwal kampus dengan jadwal pertemuan yang ada di agenda PKK.

\section{METODE PELAKSANAAN}

Kegiatan pengabdian kepada masyarakat dilaksanakan dalam bentuk penyuluhan hukum dengan menggunakan metode ceramah oleh tim penyuluh yang kemudian setelah selesai pemaparan materi dilanjutkan denga sesi tanya jawab atau diskusi, ataupun diberikan ruang bagi seluruh yang hadir untuk memberi tanggapan, masukan, kritikan, maupun sanggahan. Dengan demikian akan terbangun suasana yang hidup dimana peserta yang hadir ikut aktif bersuara dengan menyampaikan gagasan atau pendapatnya.

Untuk memudahkan pelaksanaan penyampaian materi penyuluhan kepada para peserta dibagikan makalah yang sudah dipersiapkan dan diperbanyak sejumlah peserta yang diperkirakan hadir. LCD tidak bisa kita pakai sebagai alat bantu dikarenakan tempat pertemuan dilakukan di rumah salah seorang pengurus yang kondisinya tidak mendukung untuk penataan pemakaian LCD.

Mahasiswa dilibatkan dalam membantu kelancaran pelaksanaan penyuluhan ini, seperti membantu presensi hadir peserta, membagi makalah, mendokumentasikan acara. Hal ini dimaksudkan sebagai salah satu sarana dalam melatih agar mahasiswa belajar bagaimana bekerjasama, melatih keberanian berbicara, maupun melatih bagaimana cara penyelesaian ketika menghadapi permasalahan yang terjadi.

Acara penyuluhan bisa berjalan lancar sesuai yang telah direncanakan berkat kerjasama dan koordinasi yang dilakukan dua tiga bulan sebelumnya antara pihak kampus denga koordinator pengurus PKK desa Malangjiwan sebagai mitra dalam pengabdian masyarakat kali ini.

HASIL DAN PEMBAHASAN 
Pengabdian pada masyarakat berupa penyuluhan hukum dengan thema: "Meningkatkan Peran Serta Masyarakat dalam Mengupayakan Kesejahteraan Lanjut Usia", yang merupakan sosialisasi UndangUndang Nomor 13 Tahun 1998 Tentang Kesejahteraan Lanjut usia, telah dilaksanakan di desa Malangjiwan, Colomadu, Karanganyar, dalam acara pertemuan Ibu-ibu Pengurus PKK yang telah diprogram secara rutin waktu pelaksanaannya, dengan isian acara berupa koordinasi kegiatan serta isian lain berupa informasi-informasi yang berfaedah bagi anggota PKK.

Dihadiri lebih dari tiga puluh orang pengurus PKK yang merupakan kader terbaik dalam pemberdayaan dan kesejahteraan keluarga, maka materi tentang upaya mensejahterakan kaum lansia sangat pas atau sejalan dengan tujuan keberadaan organisasi PKK, di mana kaum perempuanlah yang secara keseharian sangat berperan dalam mensejahterakan seluruh anggota keluarganya, termasuk kaum lansia yang dimilikinya.

Meski sudah lama aktif sebagai penurus PKK, namun ketika tim menanyakan apakah ada yang tahu bila di negara ini memiliki undang-undang tentang lansia, ternyata belum ada satupun yang mengetahuinya. Secara keseharian mereka telah melakukan perbuatan-perbuatan yang memuliakan kaum lansia, namun itu dilakukan berdasar kebiasaan turun temurun atau karena pengamalan dari ajaran agama yang dianutnya. Sedangkan aturan negara yang mengatur tentang kewajiban serta mendorong masyarakat untuk melakukan tugas mulia dalam upaya yang harus dilakukan untuk membuat sejahtera kaum lansia dalam rupa undang-undang sama sekali belum diketahui.

Salah satu pertimbangan dibuatnya undang-undang tentang kesejahteraan lanjut usia tersebut adalah kesadaran bahwa mengupayakan peningkatan kesejahteraan kaum lanjut usia pada hakikatnya merupakan pelestarian nilai nilai keagamaan dan kebudayaan bangsa. Mengupayakan kehidupan yang sejahtera bagi kaum lansia merupakan salah satu bentuk pengamalan ajaran agama, juga keluhuran budi pekerti dalam budaya bangsa kita. Untuk itu sudah sewajarnya hak-hak kaum lansia yang sudah diatur dalam undang-undang tersebut wajib diupayakan terpenuhinya. Pemerintah sebagai pihak yang bertanggungjawab, dan seluruh masyarakat diharapkan peranserta dan dukungannya.

Beberapa hal yang diatur oleh undang undang tersebut sebagai upaya peningkatan kesejahteraan sosial lanjut usia adalah dilaksanakannya pelayanan:

(a). Keagamaan dan mental spiritual; 
(b). Kesehatan;

(c). Kesempatan kerja;

(d). Pendidikan dan pelatihan;

(e). Kemudahan dalam penggunaan fasilitas, sarana, dan prasarana umum;

(f). Kemudahan dalam layanan dan bantuan hukum;

(g). Perlindungan sosial;

(h). Bantuan sosial.

Pemerintah belum bisa merealisasikan secara keseluruhan hal hal tersebut di atas, untuk itu masih sangat terbuka dukungan dan peran serta masyarakat untuk mewujudkannya.

Peningkatan kesejahteraan lansia melalui pelayanan keagamaan dan spiritual adalah yang paling banyak diselenggarakan oleh masyarakat. Pengajian, ceramah, dll banyak dan rutin penyelenggaraannya di masyarakat.

Pelayanan kesehatan dalam rangka peningkatan kesejahteraan lansia juga sudah banyak yang turut mengambil bagian. Posyandu lansia juga telah menjadi program bersama antara puskesmas dengan desa sehingga dijadwalkan pemeriksaan berkala untuk lansia. Bahkan sudah banyak pula tempat-tempat ibadah yang menyediakan layanan khusus bagi pengecekan kesehatan lansia. Termasuk di rumah sakit tertentu membuka poliklinik khusus bagi lansia.

Kesempatan kerja bagi lansia belum banyak yang menyediakan. Lansia yang masih potensial bila tersedia lapangan kerja yang bisa menampung dirinya untuk bisa menyalurkan eksistensinya, maka hal tersebut akan sangat membantu lansia tersebut hidup sejahtera karena merasa masih menjadi orang yang berguna, tidak menggantungkankan hidupnya hanya pada bantuan atau belas kasihan dari orang lain.

Pendidikan dan pelatihan bagi lansia rasa-rasanya menjadi barang langka karena tidak mudah kita dapati. Mungkin bukan hal yang mudah pula untuk mengadakan pendidikan dan pelatihan apa yang cocok dan bermanfaat bagi lansia. 
Kemudahan dalam penggunaan fasilitas, sarana dan prasarana umum bagi lansia sudah banyak diupayakan. Tempat tempat umum telah dibangun fasilitas yang ramah buat kaum lansia.

Salah satu hal yang muncul dan menjadi perbincangan yang cukup seru dalam acara penyuluhan tersebut adalah hal kemudahan dan layanan bantuan hukum bagi lansia. Kasus Ratna Sarumpaet yang masuk dalam kategori telah lansia harus mengalami penderitaan terpaksa menginap di hotel prodeo alias menjadi seorang tahanan akibat "keisengannya" dalam menggunakan media sosial.

Bila pelaku tindak pidana masih berusia anak, yaitu kurang dari 18 tahun, maka sistem hukum di Indonesia memberikan keringanan keringanan karena sudah ada aturan hukum yang mengaturnya, yaitu ada undang-undang perlindungan anak serta undangundang sistem peradilan pidana anak. Namun bila lansia terpaksa harus berhadapan hukum, meski secara fisik mereka lemah, dan secara psikis banyak mengalami kemunduran, namun ternyata belum ada produk hukum atau perundang-undangan yang memberikan kekhususan atau keringanan atau keistimewaan sebagaimana halnya yang diberikan kepada anak. Bahkan pegiat-pegiat sosial yang biasa disebut lembaga swadaya masyarakat (LSM) banyak yang peduli dengan nasib anak yangmenjadi korban maupun pelaku tindak pidana, namun tidak banyak (tidak ada?) LSM yang berminat atau peduli pada lansia yang memerlukan layanan atau bantuan hukum. Kasus yang dialami Ratna Sarumpaet hanya salah satu contoh diantara sekian banyak kasus pidana yang pelakunya adalah kaum lansia. Belum lagi kaum lansia yang sangat besar berpotensi menjadi korban tindak pidana. Dalam posisi sebagai pelaku maupun sebagai korban tindak pidana, mereka belum memperoleh pelayanan dan bantuan hukum yang layak dari pemerintah maupun dari masyarakat.

Perlindungan sosial dalam pengertian jaminan sosial bagi kaum lansia potensial belum menjadi program pemerintah yang membumi, namun untuk bantuan sosial yang diperuntukkan bagi kaum lansia tidak potensial sudah lama dilaksanakan oleh pemerintah dalam bentuk pemberian sembako, bantuan langsung tunai, dll.

\section{PENUTUP}

Turut serta dalam mensejahterakan kaum lansia adalah amanat undang-undang untuk kita usahakan dapat kita laksanakan seoptimal mungkin.Meski undang undang menyatakan 
bahwa pemerintahlah yang prinsipnya berkewajiban mengupayakan kesejahteraan kaum lansia, namun sebagai warga negara yang baik, yang menyadari keterbatasan pemerintah dalam mewujudkan kebaikan tersebut, maka seberapa yang bisa kita lakukan hendaklah semaksimal mungkin kita ujudkan sebagai bukti rasa cinta kita kepada negara Indonesia tercinta dan sebagai wujud syukur kita kepada Tuhan yang Maha Kasih atas begitu besar anugerahnya yang telah diberikan kepada kita. Kesadaran ibu-ibu PKK akan amanat Undang Undang Nomor 13 Tahun 1998 Tentang Kesejahteraan Lanjut Usia semoga mampu menjadi virus yang menulari orang-orang di sekitarnya untuk mengupayakan kesejahteraan kehidupan kaum lansia.

\section{DAFTAR PUSTAKA}

Undang-undang Dasar 1945

Undang-undang Republik Indonesia No.13 Th 1998 Tentang Kesejahteraan Lanjut Usia

Peraturan Pemerintah No 43 Th 2004 Tentang Pelaksanaan Upaya Peningkatan Kesejahteraan Sosial Lanjut Usia 